\begin{tabular}{l|c|c}
\hline \multicolumn{1}{c|}{ Jurnal Penelitian Kesmasy } & Vol. 2 No. 1 & Edition: May-October 2019 \\
\hline \multirow{2}{*}{ Received: 14 October 2019} & http://ejournal.delihusada.ac.id/index.php/JPKSY & Accepted: 25 October 2019 \\
\cline { 2 - 3 } & Revised: 12 October 2019 & \\
\hline
\end{tabular}

\title{
POLA SIDIK JARI DAN SUDUT AXIAL TRIRADIUS DIGITAL (ATD) PADA NARAPIDANA LAKI - LAKI DI TAHANAN TITIPAN (TAHTI) POLDA SUMATERA UTARA
}

\author{
Ismurizal \\ Universitas Islam Sumatera Utara, Jl. STM no. 77 Medan \\ Email:dr.ismu12@gmail.com
}

\begin{abstract}
Dermatoglyphics can be used not only to identify an individual's identity but also to determine chromosomal diseases, talents, potentials, and individual personalities. Several studies were conducted to prove that dermatoglyphics have a tendency that is typical of inmates. This study aimed to find out how the ATD fingerprint and angular patterns in prisoners in the Male North Sumatra Regional Police Correctional Institution. The research sample through total sampling. The research data is in the form of fingerprint patterns and ATD angles, data collection for fingerprint patterns by attaching the fingertips of the right and left hands to the Digital person Fingerprint reader and the results are analyzed on 10 fingers. ATD angles data were obtained by applying all palmar surfaces with Blue Ink and affixed to the observation sheet to calculate the angle of ATD. Data were analyzed univariately for the type of fingerprint pattern and the angle of ATD.
\end{abstract}

Keywords: Dermatoglifi, criminals, fingerprint pattern, ATD angle

\section{PENDAHULUAN}

Secara etimologis Dermatoglyphics berasal dari dua kata yaitu Derma yang artinya kulit dan Glyphe yang artinya mengukir, berarti dapat diartikan bahwa dermatoglifi adalah mengukir pada kulit (Aida, 2014). Sedangkan menurut Dermatoglifi adalah pengetahuan mengenai gambaran sulur-sulur yang terdapat pada permukaan ujung jari tangan, telapak tangan, ujung jari kaki, telapak kaki dan lipatan kulit (crease) telapak tangan. Dermatoglifi sendiri memiliki 4 bagian utama yaitu tipe pola sidik jari, jumlah triradius, jumlah sulur total dan sudut Axial Triradius Digital/ATD (Campbell, 1998; Appelbaum, 2015).

Sidik jari adalah identitas setiap individu, oleh karena itu sidik jari setiap individu berbeda-beda. Sidik jari telah digunakan untuk keperluan identifikasiseorang individu, mengetahui bakat, potensi dan kepribadian individu tersebut, hubungan keturunan, maupun membantu diagnosis suatu penyakit. Tidak ada individu yang memiliki sidik jari yang sama bahkan pada kembar identik sekalipun. Bahkan pada individu yang sama tidak akan ada dua jari yang memiliki pola sidik jari yang sama.

Pola dermatoglifi terbentuk di ujung jari tangan, telapak tangan, ujung jari kaki, telapak kaki dan lipatan kulit telapak tangan pada akhir trimester kedua dan tidak pernah berubah kecuali mengalami kerusakan yang parah akibat pengaruh lingkungan seperti terbakar atau akibat bekas luka. Sudut ATD adalah sudut yang dibentuk garis hubung dari triradius-a ke triradius-t dan dari triradius-t ke triradius-d. Rata-rata sudut ATD pada populasi normal adalah antara $35^{\circ}-50^{\circ}$ (Aida, 2014).

Berdasarkan pada beberapa penelitian sebelumnya sudut ATD memiliki hubungan dengan kesalahan pada kromosom dan penyakit lainnya. Penelitian oleh Aida (2014) menunjukkan bahwa sudut ATD kelompok narapidana berkisar $37^{\circ}-38^{\circ}$. Penelitian tentang pola sidik jari oleh Gustavson (2010) memperoleh hasil bahwa pada narapidana 


\begin{tabular}{l|c|c}
\hline \multirow{2}{*}{ Jurnal Penelitian Kesmasy } & Vol. 2 No. 1 & Edition: May - October 2019 \\
\hline \multirow{2}{*}{ Received: 14 October 2019} & http://ejournal.delihusada.ac.id/index.php/JPKSY & Accepted: 25 October 2019 \\
\cline { 2 - 3 } & Revised: 12 October 2019 & \\
\hline
\end{tabular}

dengan kasus pelanggaran pelaku seksual didapatkanhasil pola ulnar loop sebesar $46,9 \%$ dan pola whorl sebesar $38,8 \%$. Sedangkan di Indonesia tepatnya di kota Medan pernah dilakukan penelitian oleh Beatrice (2009) bahwa narapidana laki-laki dengan pelanggaran kasus seperti pembunuhan didapat persentase pola arch sebesar $30 \%$. Namun saat ini belum ada laporan khusus pada narapidana di Palembang.

Berdasarkan informasi dari berbagai sumber dan literatur mengenai pola dermatoglifi dan sudut ATD yang masih terbatas, penelitian tentang apakah pola sidik jari dan sudut ATD pada narapidana memiliki kecenderungan yang khas sehingga dapat membantu prediksi untuk seorang individu berpotensi melakukan tindak kriminal akan dilakukan.

Untuk itu tujuan dari penelitian ini adalah untuk mengetahui pola sidik jari dan sudut ATD pada narapidana Laki-laki di Tahanan Titipan Polda Sumatera Utara terkait: distribusi pola sidik jari, distribusi sudut ATD, dan kecenderungan tertentu terhadap pola sidik jari dan sudut ATD pada narapidana.

\section{METODE PENELITIAN}

Penelitian ini dilakukan di Tahanan Titipan Polda Sumatera Utara Jalan Tanjung Morawa. Jenis penelitian yang digunakan adalah penelitian deskriptif dengan metode survey, melalui desain penelitian cross sectional. Data yang dikumpulkan berupa: data primer, data yang dibuat oleh peneliti untuk maksud khusus menyelesaikan permasalahan yang sedang ditanganinya. Data dikumpulkan sendiri oleh peneliti langsung dari sumber dan data sekunder, data yang telah dikumpulkan untuk maksud selain menyelesaikan masalah yang sedang dihadapi. Data ini dapat ditemukan dengan cepat. Dalam penelitian ini yang menjadi sumber data sekunder adalah literatur, artikel, jurnal, serta situs di internet yang berkenaan dengan penelitian yang dilakukan.

\section{HASIL DAN PEMBAHASAN}

\section{Hasil Penelitian}

Dari hasil penelitian yang dilakukan dapat melihat pola sidik jaridan sudut ATD pada narapidana Laki-laki di Tahanan Titipan Polda Sumatera Utara

\section{Analisa Univariat}

Pada karakteristik sampel didapatkan bahwa untuk karakteristik usiasampel yang paling banyak adalah usia remaja akhir dan dewasa akhir yaitu 29,27\%, persentase sampel paling banyak untuk karakteristik agama adalah agama islamyaitu $70,73 \%$, untuk karakteristik suku adalah suku batak yaitu 39,02\% dan untuk karakteristik pendidikan terakhir adalah SMA/SMK yaitu $39,02 \%$. Karakteristik sampel distribusi Pola Sidik Jari dan Sudut ATD dapat dilihat pada table berikut ini.

Tabel 3.1 Karakteristik Sampel Data Responden

\begin{tabular}{llcc}
\hline \multicolumn{2}{c}{ Karakteristik } & f & $\mathbf{( \% )}$ \\
\hline $\begin{array}{l}\text { Usia } \\
\text { (tahun) }\end{array}$ & $\begin{array}{l}\text { Remaja akhir } \\
\text { (17-25) }\end{array}$ & 12 & 29,27 \\
& $\begin{array}{l}\text { Dewasa awal } \\
\text { (26-35) }\end{array}$ & 11 & 26,83 \\
& Dewasa akhir & 12 & 29,27 \\
& (36-45) & & \\
& Lansia awal & 3 & 7,31 \\
& (46-55) & & \\
& Lansia akhir & 2 & 4,88 \\
& (56-65) & & \\
& Manula (>65) & 1 & 2,44 \\
\hline Agama & Islam & 29 & 70,73 \\
& Kristen & 11 & 26,83 \\
& Kong hu cu & 1 & 2,44 \\
\hline Suku & Batak & 16 & 39,02 \\
& Jawa & 12 & 29,27 \\
& Melayu & 7 & 17,08 \\
& Sunda & 3 & 7,31 \\
& Aceh & 2 & 4,88 \\
& Tionghoa & 1 & 2,44 \\
\hline Pendidikan & Tidak sekolah & 2 & 4,88 \\
Terakhir & SD & 12 & 29,27 \\
& SMP & 4 & 9,76 \\
& SMA/SMK & 16 & 39,02 \\
& D3 & 4 & 9,76 \\
& S1 & 3 & 7,31 \\
\hline
\end{tabular}




\begin{tabular}{l|c|c}
\hline \multirow{2}{*}{ Jurnal Penelitian Kesmasy } & Vol. 2 No. 1 & Edition: May- October 2019 \\
\hline \multirow{2}{*}{ Received: 14 October 2019 } & http://ejournal.delihusada.ac.id/index.php/JPKSY & Accepted: 25 October 2019 \\
\cline { 2 - 3 } & Revised: 12 October 2019 & \\
\hline
\end{tabular}

Berdasarkan jenis kejahatan umum yang dilakukan para narapidana, terdapat 36 strata, namun pada penelitian ini hanya narapidana kejahatan pembunuhan dan pencurian yang diambil sebagai sampel, dengan jumlah sampel paling banyak yaitu 22 orang pada strata pencurian. Lihat tabel 3.2.

Tabel 3.2 Jumlah Narapidana Tiap Strata Kejahatan Umum

\begin{tabular}{lcc}
\hline \multicolumn{1}{c}{ Jenis Kejahatan } & n & (\%) \\
\hline Pembunuhan & 19 & 46,3 \\
Pencurian & 22 & 53,7 \\
\hline Total & 41 & 100,00 \\
\hline
\end{tabular}

Hasil uji pola sidik jari terhadap sampel penelitian didapatkan dari 10 jari tangan dari masing-masing sampel sehingga diperoleh dari 41 sampel didapatkan hasil 410 pola sidik jari. Hasil lalu diklasifikasikan menjadi 8 pola, yaitu: simple arch, tented arch, ulnar loop, radial loop, simple whorl, central pocket whorl, double loop whorl dan accidental whorl. Hasil sidik jari diperlihatkan pada gambar 3.1. berikut.

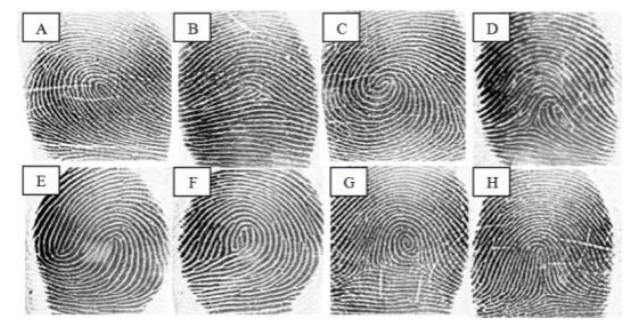

Gambar 3.1. Hasil Pemeriksaan Sidik Jari Narapidana

Sumber: Hasil pemeriksaan sidik jari Keterangan:

A: Ulnar loop (pada tangan kanan)

B: Simple arch

$\mathrm{C}$ : Simple whorl

D:Radial loop (pada tangan kiri)

E: Double loop whorl

F: Central pocket whorl

G: Accidental whorl

$\mathrm{H}$ : Tented arch

Pada tabel 3.3 didapatkan pola sidik jari dengan frekuensi paling besar adalah pola ulnarloop yaitu 257 jari $(62,7 \%)$ dan frekuensi paling sedikit adalah pola accidental whorl yaitu 6 jari $(1,5 \%)$.
Tabel 3.3 Distribusi Frekuensi Pola Sidik Jari

\begin{tabular}{lcc}
\hline \multicolumn{1}{c}{ Pola Sidik Jari } & $\mathbf{n}$ & $\mathbf{( \% )}$ \\
\hline Accidental Whorl & 6 & 1,5 \\
Central Pocket Whorl & 14 & 3,4 \\
Double Loop Whorl & 44 & 10,7 \\
Radial Loop & 9 & 2,2 \\
Simple Arch & 12 & 2,9 \\
Simple Whorl & 59 & 14,4 \\
Tented Arch & 9 & 2,2 \\
Ulnar Loop & 257 & 62,7 \\
\hline Total & $\mathbf{4 1 0}$ & $\mathbf{1 0 0 , 0}$ \\
\hline
\end{tabular}

Berdasarkan Hasil pemeriksaan pada setiap strata kejahatan umum ditemukan persentase pola yang paling tinggi adalah pola ulnarloop. Lihat tabel 3.4

Tabel 3.4 Distribusi Frekuensi Pola Sidik Jari pada Strata Kejahatan Umum

\begin{tabular}{|c|c|c|c|c|}
\hline \multirow{3}{*}{ Pola Sidik Jari } & \multicolumn{4}{|c|}{ Strata Kejahatan Umum } \\
\hline & \multicolumn{2}{|c|}{ Pembunuhan } & \multicolumn{2}{|c|}{ Pencurian } \\
\hline & $\mathbf{n}$ & $\%$ & $\mathbf{n}$ & $\%$ \\
\hline Accidental whorl & 3 & 1,60 & 3 & 1,40 \\
\hline Central pocket whorl & 5 & 2,63 & 9 & 4,10 \\
\hline Double loop whorl & 15 & 7,89 & 29 & 13,2 \\
\hline Radial loop & 5 & 2,63 & 4 & 1,80 \\
\hline Simple arch & 6 & 3,16 & 6 & 2,70 \\
\hline Simple whorl & 24 & 12,63 & 35 & 15,9 \\
\hline Tented arch & 9 & 4,73 & 0 & 0,00 \\
\hline Ulnar loop & 123 & 64,73 & 134 & 60,90 \\
\hline
\end{tabular}

Hasil pemeriksaan dan penyelidikan terhadap sudut ATD pada penelitian ini dibagi menjadi 3 kategori yaitu, kurang dari $35^{\circ}$, $35^{\circ}-50^{\circ}$ dan lebih dari $50^{\circ}$ untuk setiap tangan kanan dan kiri. Lihat gambar 3.2.

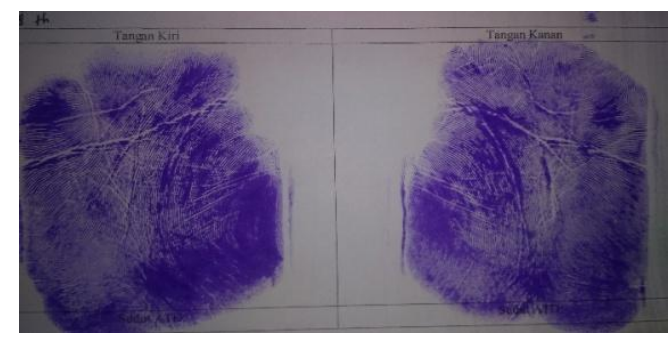

Gambar 3.2 Hasil Pengambilan Sudut ATD

Sumber: milik sampel narapidana

Distribusi frekuensi sudut ATD tangan kanan dan kiri dapat dilihat pada tabel 3.5.Pada penelitian ini didapatkan hasil yang sama pada kedua telapak tangan yaitu sudut ATD $<35^{\circ}$ sebesar $2,44 \%$, sudut ATD $35^{\circ}-50^{\circ}$ 


\begin{tabular}{l|c|c}
\hline \multicolumn{1}{|c|}{ Jurnal Penelitian Kesmasy } & Vol. 2 No. 1 & Edition: May- October 2019 \\
\hline \multirow{2}{*}{ Received: 14 October 2019 } & http://ejournal.delihusada.ac.id/index.php/JPKSY & Accepted: 25 October 2019 \\
\cline { 2 - 3 } & Revised: 12 October 2019 & \\
\hline
\end{tabular}

sebesar $90,24 \%$ dan sudut ATD $>50^{\circ}$ sebesar $7,32 \%$.

Tabel 3.5 Distribusi Frekuensi Sudut ATD

\begin{tabular}{ccccc}
\hline $\begin{array}{c}\text { SUDUT } \\
\text { ATD }\end{array}$ & \multicolumn{2}{c}{ Tangan kanan } & \multicolumn{2}{c}{ Tangan kiri } \\
$\mathbf{f}$ & $\mathbf{( \% )}$ & $\mathbf{f}$ & $\mathbf{( \% )}$ \\
\hline$<35^{\circ}$ & 1 & 2,44 & 1 & 2,44 \\
$35^{\circ}-50^{\circ}$ & 37 & 90,24 & 37 & 90,24 \\
$>50^{\circ}$ & 3 & 7,32 & 3 & 7,32 \\
\hline Total & 41 & 100,00 & 41 & 100,00 \\
\hline
\end{tabular}

\section{Pembahasan}

Pada hasil penelitian ini didapatkan bahwa persentase pola sidik jari paling banyak pada narapidana laki - laki di tahanan titipan polda sumatera utara adalah ulnarloop yaitu sebesar $62,7 \%$. Pada penelitian ini juga didapatkan hasil bahwa pada tiap strata persentase pola yang paling tinggi adalah ulnarloop dan setiap sampel narapidana kejahatan umum pasti memiliki pola ulnarloop pada jari tangannya.

Walaupun pada penelitian ini tidak menggunakan kelompok kontrol sebagai pembanding, namun apabila hasil penelitian ini dibandingkan dengan individu normal maka kemungkinan akan ada perbedaan antara kecenderungan pola narapidana dan individu normal, karena menurut Mundijo (2017) kecenderungan pola pada individu normal adalah pola whorl, perbedaan ini kemungkinan terjadi karena Mundijo melakukan penelitian dengan orang tua responden $90 \%$ memiliki pola sidik jari whorl sehingga diturunkan ke anaknya, sedangkan pada penelitian ini karena keterbatasan peneliti, maka tidak dapat diketahui pola sidik jari pada orang tua dari sampel narapidana.

Namun hasil penelitian ini jika dibandingkan dengan penelitian oleh Sintaningtyas (2010) yang mendapatkan hasil bahwa persentase pola sidik jari pada orang normal paling tinggi adalah pada pola ulnarloop yaitu $54,7 \%$, sehingga tidak ada kecenderunganyang khas pada pola sidik jari narapidana. Kemunculan persentase pola ulnar loop yang tinggi pada 10 jari tangan pada hasil penelitian ini berbeda dengan hasil penelitian oleh Mundijo (2019) yang menyebutkan bahwa pada narapidana perempuan frekuensi pola yang tinggi adalah pola arch.

Perbedaan ini kemungkinan terjadi karena faktor perbedaan etnik dan ras, karena penelitian Pricilla menggunakan sampel populasi dari negara bagian Anambra, sedangkan dalam penelitian ini peneliti tidak membagi sampel dalam berbagai etnik dan ras, dan untuk faktor lingkungan baik pada penelitian Pricilla maupun penelitian ini tidak dilakukan pembagian karakteristik lingkungan pada sampel yang digunakan.

Hasil yang berbeda juga didapatkan dari hasil penelitian Beatrice (2009) bahwa pada narapidana laki-laki dengan pelanggaran kasus seperti pembunuhan didapat persentase pola arch sebesar $30 \%$ sedangkan hasil penelitian ini adalah persentase pola terbesar pada nrapidana laki-laki adalah pola ulnarloop, perbedaan ini juga kemungkinan akibat perbedaan etnik dan ras, dimana Beatrice menggunakan sampel populasi laki-laki di lapas Tanjung Gusta Medan.

Menurut Wang (2014), tidak ada perbedaan yang signifikan terhadap distribusi frekuensi pola sidik jari laki-laki dan perempuan. Siburian (2010) mengatakan bahwa dermatoglifi merupakan suatu manifestasi genetik yang dikendalikan oleh poligenik yang berkembang selama masa gestasi, dimana pola dasarnya tidak akan berubah seumur hidup. Variasi pola dermatoglifi dipengaruhi oleh etnik dan ras karena dipengaruhi oleh beberapa gen yang saling berinteraksi yang akhirnya akan menghasilkan pola yang dominan pada suatu populasi yang berbeda dengan populasi lainnya dan juga dapat dipengaruhi oleh gangguan pada perkembangan saraf dan gangguan pada awal perkembangan otak (Zhang dkk, 2010).

Hasil penelitian yang sama didapatkan dari penelitian yang dilakukan oleh Malhotra (1992), Gustavson (2010) dan Pandey (2014) dimana pada ketiga penelitian ini didapatkan bahwa pada narapidana, distribusi fekuensi 


\begin{tabular}{l|r|c}
\hline \hline Jurnal Penelitian Kesmasy & Vol. 2 No. 1 & Edition: May - October 2019 \\
\hline \multirow{2}{*}{ Received: 14 October 2019} & http://ejournal.delihusada.ac.id/index.php/JPKSY & Accepted: 25 October 2019 \\
\cline { 2 - 3 } & Revised: 12 October 2019 & \\
\hline
\end{tabular}

pola sidik jari yang paling tinggi adalah pada pola ulnar loop. Hal ini kemungkinan karena pola ulnar loop adalah pola yang paling umum ditemukan (Bansal, 2014).

Pada hasil penelitian ini persentase terbesar sudut ATD berada di rentang normal yaitu $35^{\circ}-50^{\circ}$ sebesar $90,2 \%$. Walaupun belum ada penelitian yang mengkaji mengenai hubungan sudut ATD dengan usia, namun Pakhale (2012) menyebutkan bahwa sudut ATD dipengaruhi oleh faktor usia melalui pengaruhnya pada ukuran sulur, dimana selain dipengaruhi oleh lingkungan sebelum lahir, sudut ATD lebih dipengaruhi oleh lingkungan setelah lahir, sudut ATD cenderung berubah mengikuti ukuran sulur yang sejalan dengan perkembangan telapak tangan dan kaki. Hasil pada sudut ATD juga dapat dipengaruhi oleh jarak antar jari saat dilakukannya proses pengecapannya dan tekanan oleh telapak tangan sampel saat melakukan pengambilan cap telapak tangan (Bala dkk, 2015). Berdasarkan hasil tersebut maka tidak ada perbedaan kecenderungan yang khas pada sudut ATD narapidana dan individu normal.

Hal ini berarti pola sidik jari dan sudut ATD pada narapidana belum bisa dijadikan ciri yang khas sebagai pembeda pada narapidana dan individu normal, karena memang pada dasarnya dermatoglifi digunakan hanya sebagai alat bantu diagnosis apakah seseorang dengan pola tertentu memilki kecenderungan melakukan tindak kriminal ataupun suatu penyakit tertentu oleh karena itu masih perlu dilakukan penelitian lanjutan pada dermatoglifi untuk memastikan hal tersebut.

\section{KESIMPULAN}

Kesimpulan yang dapat diambil antara lain:

1. Distribusi pola sidik jari pada narapidana laki - laki yaitu ulnar loop (62,7\%), simple whorl $(14,4 \%)$, double loop whorl $(10,7 \%)$, central pocket whorl $(3,4 \%)$, simple arch $(2,9 \%)$, radial loop dan tented arch $(2,2 \%)$ dan accidental whorl $(1,5 \%)$.
2. Distribusi besar sudut ATD narapidana laki - laki pada telapak tangan kanan dan kiri, yaitu sudut ATD $<35^{\circ}$ sebesar $2,4 \%$, sudut ATD $35^{\circ}-50^{\circ}$ sebesar $90,2 \%$ dan sudut ATD $>50^{\circ}$ sebesar $7,3 \%$.

3. Tidak ada kecenderungan tertentu terhadap pola sidik jari maupun sudut ATD pada narapidana laki - laki di tahanan titipan polda sumatera utara berdasarkan strata kejahatan umum.

\section{DAFTAR PUSTAKA}

Aida, N., Roesma D.I., dan Tjong, D.H. (2014). Analisis sudut ATD pada narapidana. Jurnal Biologi Universitas Andalas, Vol. 3 (1): 27-33.

Appelbaum, P.S., dan Scurich, N. (2015). Impact of Behavioral Genetic Evidence on the Adjudication of Criminal Behavior. J. Am Acad Psychiatry Law. Vol. 42 (1): 91-100.

Bala, et.al. (2015). Fingerprints \& Palmar Dermatoglyphics. Diakses 17 Agustus 2018. (http://www.dermatoglyphics.co)

Bansal, (2014). A Novel Member of the ADAMTS/ Metal Lospondin Gene Family. Genomics, Vol. 67: 343-50.

Beatrice, E. (2009). Perbandingan Pola Multifaktor Sidik Jari Narapidana Di Lembaga Permasyarakatan Tanjung Gusta Medan Dengan Pria Normal Di Luar Lembaga Permasyarakatan. [Skripsi] Medan: Universitas Sumatra Utara.

Campbell. 1998. Fingerprints \& Palmar Dermatoglyphics. Diakses 17 Agustus 2018. (http://www.dermatoglyphics.co)

Gustavson, K.H., Modrzewska, K., \& Sjöquist, K.E. (2010). Dermatoglyphics in Individuals with Asocial Behaviour. Upsala J Med Sci, Vol. 99: 63-67.

Malhotra, (1992). ).A Comparative Study of Dermatogly Phicsin Individuals with Normal Occlusions and Malocclusions. Journal of Clinical and Diagnostic Research, Vol. 7 (12).

Mundijo, T., \& Purwoko, M. (2017). Dominasi Pewarisan Pola Sidik Jari Whorl dalam Keluarga Karyawan Fakultas Kedokteran 


\begin{tabular}{l|r|c}
\hline \multirow{2}{*}{ Jurnal Penelitian Kesmasy } & Vol. 2 No. 1 & Edition: May- October 2019 \\
\hline \multirow{2}{*}{ Received: 14 October 2019} & http://ejournal.delihusada.ac.id/index.php/JPKSY & Accepted: 25 October 2019 \\
\cline { 2 - 3 } & Revised: 12 October 2019 & \\
\hline
\end{tabular}

Universitas Muhammadiyah Palembang. Jurnal Kedokteran Brawijaya, Vol. 29 (4): 312-315.

Mundijo, T., \& Rezky, M. (2019). Dermatoglifi Narapidana di Palembang. Syifa' MEDIKA: Jurnal Kedokteran dan Kesehatan. Vol. 9: 86.

Pakhale, S., (2012). Axial Triradius as Apreliminary Diagnostic Tool in Patients of Mental Retardation. The Internet Journal of Biological Anthropology, Vol. 4 (1).

Pandey, (2014). Fingerprint Patterns and the Analysis of Gender Differences in the Patterns Based on the $U$ Test. International Transaction of Electricaland Computer Engineers System, Vol. 2 (3): 88-92.

Siburian, J., Anggreini, E., \& Hayati, S.F. 2010. Analisis Pola Sidik Jari Tangan dan Jumlah Sulur Serta Besar Sudut ATD Penderita Diabetes Mellitus di Rumah Sakit Umum Daerah Jambi. Biospecies, Vol. 2 (2): 12 -17.

Sintaningtyas, L.J. 2009. Pola Dermatoglifi pada Pasien Skizofrenia di Rumah Sakit Jiwa Daerah Surakarta. [Skripsi] Fakultas Kedokteran Universitas Sebelas Maret.

Wang, L., \& Alexander, C.A. 2014. Fingerprint Patterns and the Analysis of Gender Differences in the Patterns Based on the $\mathrm{U}$ Test. International Transaction of Electrical and Computer Engineers System, 2014, Vol. 2(3): 88-92.

Zang, dkk., (2010). Dermatoglyphics: in health and disease-A Review. International Journal of Research in Medical Sciences, Vol. 2 (1): 31-37. 